\title{
Farklılıkların Birarada Yaşamasında Bir Sorun Alanı Olarak Ötekinin Ötekileştirilmesi
}

\author{
Prof. Dr. Ertan Özensel \\ Selçuk Üniversitesi, Edebiyat Fakültesi \\ Sosyoloji Bölümü \\ ertanozensel@gmail.com
}

Öz

Farklılıkların bir tehdit unsuru olarak algılanması sonucunda ortaya çıkan süreç kişi ya da grupların diğerini ötekileştirmesi sonucunu ortaya çıkarmaktadır. Ötekileştirme "ben" ve "biz" in dışındakilerin olumsuz olarak algılanmasıdır. Ötekileştirme sadece hakim grup tarafından diğerlerine yapılmaz, aynı zamanda hakim olmayan gruplar tarafından da güçlü gruba karşı da yapılabilir. Bu nedenle insanlık tarihi boyunca öteki ya da diğeri tasavvuru sürekli olarak varlığını sürdürmüştür. Dahası öteki, diğeri ile ilişkinin temel belirleyicisi de olmuştur. Ancak bir arada yaşamanın ve ötekini ötekileştirmemenin ön koşulu, herkesin kimliklerine saygı gösteren, onların temel hak ve özgürlük taleplerini ciddiye alan bir anlayışa sahip olmakla ve bunu uygulamakla mümkün olabilecektir.

Anahtar Kelimeler: Öteki, Ötekileştirme, Birlikte Yaşama.

\section{The Othering of the Other as a Problem Area in Living Together with Differences}

\begin{abstract}
As a result of perceiving differences as a threat, the process of othering of individuals or groups is revealed. The othering is the negative perception of those who are outside of 'me' and 'us'. The othering is not only done by the dominant group to others, but also by the non-dominant groups against the powerful group. Throughout the history of mankid, the other or the other imagination has existed and the other has been the main determinant of the relationship. However, the precondition of living together and not marginalizing the other can be possible by having an understanding that respects everyone's identity and takes their fundamental rights and freedom demands seriously and by implementing these acts.
\end{abstract}

Keywords: Other, Othering, Living Together. 


\section{GíRIŞ}

Toplum, doğuştan ve sonradan kazanılmış farklı özelliklere sahip kişi ve grupların belirli idealler, inançlar ve değerler etrafında bir araya gelmesiyle meydana gelen dinamik bir yapıdan oluşur. Bu bağlamda toplumların en belirgin özelliği de farklılık üzerine inşa edilmiş olmalarıdır. Toplum içinde yaşayan bireyler, toplumun hedeflediği idealler, değerler ve inançları doğrultusunda sosyal kimliklerini oluştururlar. Kimliklerin oluşumunda toplumda var olan farklılıklar ya tolera edilir ya da ön yargılarla ötekileştirilir. Kimliğin farklılık bileşenleri, önyargı, ayrımcılık, öteki ve ötekileştirme süreçleridir. Kimliğin iki önemli bileşeni vardır; "farklılık" ve "benzerlik". Farklılık, bireyi ve grubu diğerlerinden ayrıştıran bir bileşen iken, benzerlik, bireyi ve grubu diğerleriyle benzeştiren bileşenlerdir.

Bireyin sahip olduğu her türlü farklılıklara olumsuz anlamlar yüklenerek, günlük yaşamda bu farklılıkların bir tehdit unsuru olarak algılanması sonucunda ortaya çıkaran süreç ötekileştirmedir. Ötekileştirme "ben ve biz" in dışındakilerin olumsuz algılanmasını ve değersizleştirilmesi süreçlerini içerir. Dolayısıyla birey, sahip olduğu bireysel ve kolektif kimliğine olumlu atıflar yaparak, farklılıklara ve ötekilere ise olumsuz atıflar yaparak kendi kimliğini daha değerli kılar. Böylece kendi dışındakileri "ötekileştirir". Ötekileştirme sadece hakim grup tarafından diğerlerine yapılmaz, aynı zamanda hakim olmayan gruplar tarafından da baskın gruba karşı da yapılabilir. Böylece ötekileştirme iki zıt kutupta kendini inşa eder. Normallik ise iki zıt kutubun merkeze yaklaşmasıyla mümkün olabilmektedir.

$\mathrm{Bu}$ makalede farklılıkların birarada yaşamasında bir sorun alanı olan ötekinin ötekileştirilmesi üzerine kısaca bir teorik değerlendirme yapılacaktır.

\section{Günlük Yaşam ve Etkileșim}

Günlük yaşam, bireyin toplumsal yaşam içinde, temel ihtiyaçlarını karşılamak, sosyal bir varlık olmanın gerekliliklerini yerine getirmek ve yaşamın devam ettirebilmek için yapmış olduğu faaliyetleri ifade etmektedir. Birey toplumsal yaşamda genellikle ihtiyaçlarını kendi başına karşılayamaz ve başkaları ile çeşitli etkileşim ve ilişki süreçlerine girer. Bu ilişki ve etkileşim sürecinde oluşan günlük yaşam tekrarlar, alışkanlıklar, performanslar ve çaba rutinlerini içerir. Performans, günlük yaşamda bireyin diğer bireyleri etkilemek için yapmış olduğu etkinlikleri, rutin ise performans sırasında sergilenilecek önceden belirlenmiş davranış kalıplarını ifade eder (Goffman, 2012, s. 28). Toplum içindeki bireylerin davranışlarını da hayata geldiği andan itibaren sosyalleşme süreci içinde bulunduğu toplumsal çevre alanı şekillendirmektedir. "Fiilî ve potansiyel kuvvetlerin mekânı olan alan, aynı zamanda bu kuvvetlerin biçimlerinin dönüşümü ya da korunması için de mücadele edilen bir alandır" (Bourdieu ve Wacquant, 2012, s. 86). Mücadele alanı yaşam boyu devam eden bir süreçtir ve kesintiye uğramadan süregelir.

Yaşam boyu kesintiye uğramadan devam eden bu mücadele alanını Bourdieu açıklarken "oyun" metaforunu kullanır. Alanda varolan bireyler için oyunun oynanmaya değecek nitelikte olması gerekir. Alanda oynanan oyunun sonucunda oyuncu birtakım çıkarlarının karşılanmasını bekler. Eğer oyuncu bu çıkarlarının karşılanmayacağını düşünürse ya da oyun sonucunda istediğini elde edemezse oyuna dâhil olmaz. Bourdieu bu durumu da "sermaye" kavramıyla açıklar. Kişinin sahip olduğu farklı sermaye türleri vardır. Bunlar, dini, ekonomik, kültürel ya da sembolik olabilirler ve bağlama göre işlev kazanırlar. Bir toplumda ayn sınıfın üyeleri, sahip olunan sermayeleri benzer biçimde kullanma eğilimine sahiptirler. Bourdieu üyelerin bu yatkınlığını da "habitus" kavramıyla 
açıklamaya çalışır. "Habitus, aslında hem nesnel olarak sınıflandırılabilir pratiklerin üretici ilkesi hem de bu pratiklerin sinıflama sistemidir. Temsil edilen toplumsal dünya, yani yaşam tarzları boyutu, habitusu belirleyen bu iki kabiliyet arasında, yani 'sınıflandırılabilir pratikler ve yapıtlar üretme kabiliyeti' ile 'bu pratikler ve ürünleri ayırt edip değerlendirme kabiliyeti' arasındaki ilişkide oluşur ve şekillenir" (Bourdieu, 2015, s. 254).

Günlük yaşam, toplumun temel dinamiğini oluşturan sıradan insanların tarihidir. Başka bir ifade ile bu sıradan aktörün, hayatına etki eden ve biçimlendiren her şeyin toplamıdan ibarettir (Işın, 1995, s. 8). Günlük yaşam aslında sıradanlığın, tekdüzeliğin ve tabii olanın alanıdır. Eski ile yeninin, aynı ile farklının, 'ben' ile 'öteki'nin karşılaştı̆̆ı ve yine “ötekinin" “ötekileştirildiğì" alandır.

“İnsanın, ötekiyle karşılaşma serüveninin can alıcı noktası, günlük yaşamda kurulan yüz yüze ilişkiler sonucu edindiği deneyimleridir. Hiçbir etkileşim türü yüzyüze kurulan iletişim kadar gerçekçi değildir. Hiçbir sosyal ilişki türünde yüzyüze kurulan iletişimde olduğu kadar kendiliğin dışa yansıması da söz konusu değildir" (Yıdırım, 2019, s. 17-18). Günlük yaşamdaki iletişimin doğasında başkalarıyla sürekli etkileşim ve karşılıklı paylaşım vardır. Bu paylaşımlar, aile içi ilişkiler, arkadaş ilişkileri, komşuluk ilişkileri ve iş ilişkileri gibi süreçlerde ortaya çıkar ve devam ederler (Berger ve Luckmann, 2008, s. 44). Günlük yaşam, her bireye çeşitli fırsatlar sunar. Dolayısıyla günlük yaşamın incelenmesi toplumsal olanın anlaşılmasında köşe taşı görevi yapar. Günlük yaşam, toplumsal eylemin bir anlamda karanlık odasıdır. Bildiği gibi karanlık oda, fotoğrafların gün yüzüne çıkarıldığı ortamlardır. İște günlük yaşam da bu bağlamda toplumsal eylemin karanlık odasıdır (Certeau, 2009). Toplumsal yaşamda varolan ve olagelen gerçekliğin bir şekilde olduğu gibi ortaya çıkmaktadır.

\section{Farklılık, Benzerlik ve Kimliğin İnşası}

Farklılık ve benzerliği anlamanın en kısa yolu, bu iki olguyu karşılaştırmadır. Karşılaştırma genellikle nesnel ya da soyut boyutta gerçekleştirilir. Ten rengi ya da beden yapısı gibi nesnel karşılaştırmalar ile değer ya da yaşam tarzından kaynaklanan soyut karşılaştırmalardır. Bu bağlamdaki karşılaştırmalar, farklılı̆̆ın oluşmasının kaynağının ne olduğunu ortaya çıkarır. Dolayısıyla farklılığı ne şekilde ele alırsak alalım, "farklılık/başkalık" ve "öteki” üzerinden tanımlanmayı mümkün kılmaktadır.

Birbiriyle benzer olanlar ya da benzer veya aynı fikirlere sahip olanlar arasında paylaştıkları şeyler genellikle ortak olduğu için, ilişki sürecinde fazla sorun çıkması beklenemez. Sorun genellikle bilinmeyenle dolayısıyla tecrübe edilmemiş olandan kaynaklanır. İnsanların genellikle kendileriyle ortak yönlerinin fazla olduğu kişilerle daha çok irtibatta olmaları onları sınırlı bir sosyo-demografik alana hapseder. (Mc Pherson, Smith-Lovin ve Cook, 2001, s. 415). Sürekli deneyimlediğimiz ortam bizi farkında olarak ya da olmayarak tek tipleştirdiği için, ötekiyle ilişkimiz sürekli sorun alanı olarak algılanır ve pratik yaşamda bazen kendini bir sapma olarak ortaya çıkarır.

Şüphesiz insanlık tarihi boyunca öteki ya da diğeri tasavvuru sürekli olarak varlığını sürdürmüştür ve öteki tasavvuru, diğeri ile ilişkinin temel belirleyicilerinden en önemlisi olmuştur. Her dönemde farklılığ dışlayan ya da tam tersi benimseyen anlayışlar var olagelmiştir.Bu durum daha çok, toplumların sahip olduğu medeniyet tasavvuru ile ilgilidir. Günümüzde her ne kadar pratikte uygulama alanı bulamasa da, farklılıkların giderek kabul görmesi ve önemsenmesi, tüm insanlı̆̆ kapsayan modernist büyük anlatıların, salt 
pozitivist yaklaşımların ve evrenselci/genellemeci bakış açlarının terk edilmesinin bir parçası olarak ifade etmek yerinde bir değerlendirme olacaktır.

Kişilerin günlük yaşamda sergilemiş olduğumuz roller zamana ve mekâna bağlı olarak farklılaşmaktadırlar. Bu farklılaşmanın kaynağında da, sahip olduğumuz çoğul ve farklı kimliklerimizdir. "Yüklenilen kimlik özeliklerinin bir kısmı, bizim kendiliğimiz yani öz benliğimizle ilintilidir ki bu özellikler bizi öteki bireylerden farklılaştırır. Yine yüklenilen kimlik özelliklerinin bir kısmı ise bizi bazı insan toplulukları ile benzer kılar. Benzerlikler kolektif kimliklerin oluşmasında asli unsur olarak yapılandırılır" (Yıldırım, 2019, s. 23). Dolayısıyla kimlik olgusu farklılık ve benzerlik üzerinden kurgulanarak kimlik taşıyıcılarının günlük yaşamdaki eylemlerinin sınırlarını da belirlemiş olur.

Kimlik oluşum sürecinin üç temel aşamadan meydana gelir. "Farklılaşma”, "Özreferans veya Öz-imgenin yerleşmesi" ve "Başkaları tarafından tanınması" (Therborn, 1996, s. 229). Kimlikler inşa edilirken tarihten, coğrafyadan, biyolojiden, kolektif hafızadan ve kişisel fantezilerden, güç ya da iktidar aygıtlarından ve dinsel olgulardan ana unsurlarını temin ederek oluşurlar. Ancak bireyler, sosyal gruplar ve toplumlar, tüm bu materyalleri işlerler ve toplumsal yapılarına ve zaman-mekân çerçevelerine dayanan toplumsal tespitlere ve kültürel yapılanmaya göre anlamlarını yeniden düzenlerler (Castells, 2010, s. 7). Tüm bunlarla birlikte farklı kimliklerin inşasında din, ırk, dil, cinsiyet, yaşam tarzı vb. farklı unsurlar merkezi role sahiptirler. Günümüzde bireysel kimliğin modernliği konusundaki tartışmalardan, cinsiyetçi toplumsal söylemlere, milliyetçiliğin ve etnik siyasete yönelik girişimlere kadar kimlikle ilgili çok farklı tartışma ve yaklaşımlar söz konusudur.

Bireyin kendi kimliğini oluştururken belli bir aidiyete bağlı olması, kimlik inşa sürecini kolaylaştırmaktadır. Aidiyet hissettiği grupla, bunun dışında kalan grup ya da gruplar arasındaki farklılaşma bireyin oluşturduğu kimliği pekiştirmektedir (Schnapper, 2005, s. 151). Böylece bireyin ait hissettiği gruba olan bağl1lı̆̆1 ve güveni artmaktadır.

Sonuçta kimlik, toplum tarafında kabul görmüş bir dizi farklılıklarla ilişkili olarak yapılandırılmış ve oluşmuş bir süreçtir. Bu farklılıklar kimliğin oluşturulmasında asli olan unsurlardır. Kimlik var olmak için farklılığa ihtiyaç duyar ve bu farklılığı öteki olarak kendi varlığını güvence altına almış olur (Connolly, 1991, s. 64). Böylece bireysel kimliğin oluşmasında ön plana çıkan farklılık, bireyin dışa taşan diğer bireylerden ayıran temel özelliği iken, toplumsal kimlik ise, her bir toplumsal grubun diğer gruplardan kendisini ayıran farklılıkları belirli temalar üzerinden inşa edilmesidir.

Aynıllğı ve sürekliliği içeren kimlik, kişiyi başkalarından ayırt eden duygu, düşünce, değer ve tutumların kaynaşmış yapısı ile belirlenen bütünselliklerdir. Bireyler, kimliklerini çoklu bir çatışma ortamında oluştururlar ve bu çatışmaların hem öznesi hem de nesnesi olarak farklı eksenler üzerinde, farklı şekillerde kendini konumlandırırlar. Var olan bütün farklı kimlikler birbirleriyle sürekli etkileşim içindedirler. Ancak söz konusu etkileşimler, uzlaşmaya değil farklılaşmaya yol açar. Kendini tanımlamak için farklılığa vurgu yapan kimlik, bir yandan farklılığı öteki olarak görürken, öte yandan temelde bir benzerliği, bir aidiyeti ve mensubiyeti ifade ederek, bu benzerlik üzerinden homojen bütünselliği olan "bizlik" kategorisini oluşturmaktadır (Karakaş, 2013, s. 3). Ayrıca bir arada yaşamanın ön koşulu, herkesin kimliklerine saygı gösteren, onların temel hak ve özgürlük taleplerini ciddiye alan bir anlayışa sahip olmakla ve bunu uygulamakla mümkün olabilecektir. Kimlik 
arayışı, kişinin ait olduğu topluluğa bağlanması, orada kendine yer bulması, toplumuna ve kendine güvenme ihtiyacından kaynaklanmaktadır.

\section{Öteki ve Ötekinin Ötekileştirilmesi}

Gündelik hayatta sıklıkla görebildiğimiz gibi her insanın yaşamı, ötekiyle sürekli bir kıyaslama ve karşılaştırma halindedir (Bourse, 2009, s. 99). Dolayısıyla insanoğlu öteki ile olan ilişkisini her defasında yeniden inşa eder.Bu bağlamda "ötekileştirme" sürecinin ortaya çıkmasını sağlayan farklı iktidarlar, tarihler, sınırlar ve dillerin oluşturduğu diyalog koşullarıdır. Bu durum ise bizi "kültürler, diller ve karmaşık anlam ve iktidar biçimlenişleri arasında" sonu olmayan bir yolculuğun içine çekmektedir (Chambers, 2005, s. 24).

İnsanlar, “ötekileri 'kötüler', 'kötü kalpliler', ya da 'barbarlar' olarak görüp kendilerine de 'insanlar' ya da 'iyiler', 'mükemmeller' olarak tanımlarlar. Bu tutum, her birimizde yeniden belirme eğilimi taşıdığına göre aslında, sağlam psikolojik temellere dayanmaktadır. Ne var ki, eğer onu benimseyip çeşitli kültürler üstünde yargıya varırsak, tam da mahkûm ettiklerimiz gibi davranmış oluruz" (Schnapper, 2005, s. 178). Burada kendi değer sistemimizin sınırları ortaya çıkar. Yani "ben" ya da "biz"in ötekini nasıl anlamlandırdığı, nasıl algıladığı ve nasıl davrandığı sorunsalıdır.

"Ben" ve "Öteki" arasındaki ilişkinin, birbirini sürekli kıyaslayan, tanımlayan ve yok sayan boyutuyla ontolojik karakterli olduğu söylenebilir. Ancak 'Öteki' kavramı ile 'ötekileşme' ve 'ötekileştirme' kavramları arasında şüphe götürmez derin anlamsal farklılıklar vardır. "Ben'in kendi varlık alanını ihlâl ve iğfal göndergeli bir yöntemle genişletme çabası sezilir. Sözgelimi ‘birisi, her zaman ötekidir' denildiğinde, Ben’in de kendi içinde sürekli bir öteki'yi taşıdığı anlaşılabilir. Bu yüzden 'öteki', düşman varlık değildir, aksine, kendisine yöneltilen eyleme verdiği karşılıkla ontolojik bir farklılık algılaması da yaratan 'kendine özgü' bir varlıktır. Kendini daha iyi yansıtacak bu farklılık algılaması, Ben'in etik bir değer oluşturmasına daima katkıda bulunur" (Korkmaz, 2008, s. 17). 'Öteki' kabul edilebilirin ötesinde yer buluyorsa, bunun nedeni kültürel farklılıktan çok ötekinin kendisi için de anlaşılmaz olmasındandır (Eagleton, 2011, s. 115). "Bireyler arasında ya da toplumlar arasında meydana gelen çatışmalar genellikle ayrışmalara neden olur. İster birey olsun ister toplum olsun bu çatışmanın sonuçlarının sorumluluklarını almak zorunda olan öteki açısından da sonuçlar kaçınılmaz olacaktır. Çatışma sonucunda meydana gelen ayrılıklar ise ötekileşmeye ya da yabancılaşmaya neden olacaktır" (Özalp, 2014, s. 233).

"Ben" ve "öteki" şeklinde ifade edilen iki kavramın inşası aynı zamanda biri diğerinin varlığına bağlıdır. "Ben” olmadan "öteki" olmaz. Dolayısıyla ayrımın kesişim noktası fakat aynı zamanda kendini ve ötekini inşa etmenin de başlangıç noktasıdır da. Bir arada yaşama kültürünün odak noktası da "ben" ve "öteki" arasındaki algı ve ilişkilerin niteliğinde saklıdır ve bizim ve ötekinin "ben"i ve "öteki"ni nasıl gördügü ve anlamlandırdığıdır. Kısaca diğerini "öteki" olarak mı yoksa "ötekileştirme" olarak algılayıp algılamama meselesidir (Özensel, 2016, s. 13).

“Empati tanımayı gerektirir ve sadece tanımayla gelişen bir tutumdur. Öte yandan kişi tanımadığı herhangi bir şeyin yerine kendini koyamayacağı gibi; 'insan bilmediği şeyin düşmanı' da olabilir. Dolayısıyla kişi öteki'ni tanıdıkça, ötekileştirme eğilimi de azalır" (Kurtbaş, 2013, s. 39). Ötekileştirmemenin öncelikli yolu ötekini tanımak, anlamak ve bilmektir.

SEFAD, 2020; (43): 369-378 
Ötekileştirmeye yönelik yapılan çeşitli araştırmalarının bulguları, ötekileştirmeye neden olan en önemli faktörlerin başında etnik köken ve din gelmektedir. Her etnik grup farklı kültürel öge etrafında odaklanıp birleşebilmektedirler. Her ne kadar etnik köken temelde fizyolojik bir farklılığı ifade etse de, etnik farklılıkların odaklandığı ana unsurlar daha çok sosyal süreçler sonucunda inşa edilen bir olgu olarak karşımıza çıkmaktadır.

Bilinen insanlık tarihi boyunca, insanlar etnik köken ya da aidiyetleri sebebiyle çeşitli problemler yaşadıkları bilinmektedir. Özellikle hakim etnisitenin dışında kalanlar yaşadıkları toplumda ayrımcılığa uğramışlardır. Genellikle bir toplumda devletin şekillenmesi çoğunlukla hakim grup tarafından gerçekleşir ve yine genellikle hakim grubun dışındakiler devletin imkanlarından daha az yararlanırlar. Bu durum etnikler arasındaki ayrışma, ayrımcllık ve ötekileştirmeyi körükleyerek farklılıkların birlikte yaşama imkânlarını olanaksız hale getirir (Yıldırım, 2019, s. 36). Toplumdaki farklı etnisiteler arasındaki eşitsizlikler, zaman zaman gerginliklere, tehditlere, karşılıklı düşmanlıklara ve çatışmalara yol açarlar. Hatta taraflar arasındaki bu türden algı ve davranışlar toplumsal yapının bozulmasına hatta çökmesine yol açabilmektedir.

Din ise, büyük oranda vahye dayalı olarak bireyin aile ilişkileri, arkadaş ilişkileri, iş ilişkileri ve sosyalleşme süreçleri gibi tüm insan eylemlerinin temel dinamiklerinden biridir. Din günlük yaşam içerisinde daha çok bireyin öteki ile olan temasının ahlaki zeminini oluşturur. Dinlerin siyasal, ekonomik öngörüleri ötekilerle olan ilişkilerin sınırlarını belirlemede de önemli işlevler üslenirler. Dindarlık dini uygulamaların yoğunluğunu ve tutarlılı̆̆ın ifade eder. Kamu dindarlı̆̆ı, diğer insanlarla yapılan dini faaliyetleri tanımlar. Özel dindarlık, kişinin kişisel ve açıklanmamış dini uygulamasıdır. Halk dindarlığı başkalarıyla dini inançların paylaşılmasını ifade eder (Ishii, Klopf ve Cooke, 2010, s. 60).

Dün olduğu gibi bugünde, herhangi bir dinin inananı kendi inanç alanını "öteki" üzerinden tanımlamakta ve anlamaktadır. Müslümanların çoğunluğunu oluşturduğu Türkiye'de, farklı dinler ile aynı dinin farklı yorum biçimleri diyebileceğimiz farklı mezheplerine mensup insanların bir arada yaşamaktadırlar. Her ne kadar dini farklılıklar açısından ülkemizde ciddi olarak nitelendirilebilecek sorunlar yaşanmasa da, farklı etnik, dini, mezhepsel kökenli insanların bir arada yaşadığı tüm dünyada diğer dinlere ve kültürlere dair bireyin "hakikat" ve "hikmet" arayışını güçlendirecek bir yöntem arayışına ihtiyaç hissedilmektedir.

İslam dini, temel ilkelerini ortaya koyarken, kendi dışındaki kültür ve değerleri yok saymamış, herhangi bir toplumda var olan gelenekler konusunda da genel prensiplerini belirlemiştir. Tevhide ve İslam'ın temel ilkelerine aykırı olmayan unsurları olabildiğince hoş görmüştür. İslam hukukunda yer alan "Ehl-i Kitap" ve "Zımmi" kavramları bu anlayışın pratikte yerleşmesine neden olmuştur. Böylece İslam toplumlarında farklılık ve çoğulculuk, toplumsal yaşamın bir parçası haline gelmiştir (Özensel, 2016, s. 15).

Modern Batı paradigmasında 'ben' ve 'öteki' arasında üç farklı yaklaşımın toplumsal ilişkileri belirlemesinden söz edilebilir. Bunlardan birincisi, 'ben' ve 'öteki'nin varllğı kabul edilir fakat iyi, güzel ve tam olan 'ben'e, eksik hatalı ve çirkin olan ise 'öteki'ne yüklenmesidir. 'Ben'in karşısına 'öteki'nin konumlandırılması, öznenin 'ben' ideali için bir tehdit olarak algılanmasına ve kimlik bütünlügünü olumsuz etkileyerek çatışmacı ve şizofrenik bilinçlerin doğmasına neden olmaktadır. Batının İslam dünyasına bakışı bu yaklaşıma güzel bir örnek olarak verilebilir. İkincisi, 'ben'in varlığı karşısında 'ötekinin 
'varlığına tahammül edememesi ve tamamıyla yok edilmesi gereken bir durum olarak algılamasıdır. Bu durum, 'ben' varlığının mutlak gerçek ve hakikat olarak konumlandırılmasıdır. 'Öteki' ise merkezin dışına sürülerek yok edilmek istenendir. Batının kolonyal dönemi, bu yaklaşımın en etkili örneklerinden biridir. Üçüncüsü ise 'ben' ve 'öteki' nin varlık olma iddiasının zayıflatılarak 'ben' ve 'öteki' arasındaki çatışmanın kontrol altına alınmasıdır. Bu tür ilişkide 'ben' ve 'öteki' yani her ikisi de, kendi aidiyet söylemlerinden vazgeçerek evrensel bir takım söylemler etrafında toplanılmasının amaçlanmasıdır (Kalın, 2016, s. 454-455). Fakat günümüzde de çok açık bir şekilde görüldüğü gibi, etrafında birleşilmek istenen evrensel değerlerin Batı kültürel kodlarını taşıması, kendi dışındaki diğer toplumların ötekileştirilmesinin önüne geçememektedir.

Nitekim Batının sahip olduğu kendinin dışındaki toplumlara rasyonalist ve evrenselci bakış açısı, öteki'nin kendi tarihsel süreci ve kültürel özgüllüğü içerisinde sunabileceği etik bir alan imkânını elinden almaktadır. Kendisini rasyonel akla sahip, modern, ilerlemeci olarak merkeze alan Batı için öteki, Batılı değerlere sahip olmayan bir özne olarak önsel (a priori) bir nitelendirmedir. Bu noktadan bakıldığında da Batı için öteki, ne olduğundan ziyade, ne olmadığı şeklinde tanımlanmakta ve modern benliğin sahip olduğu her şeyden yoksun olan kültürel bir nesneyi ifade etmektedir (Keyman, 2000, s. 218-222).

Bugün Batı 'ben' ve 'öteki' arasındaki çatışmanın kontrol altına alınması adına postmodern söylemleri sıklıkla dile getirse de, pratikte 'ben' ve 'öteki'ni kendi aidiyet söylemlerinden vazgeçirerek evrensel bir takım söylemler etrafında toplamaya çalıştığı görülmektedir. Hatta Batı, toplumun üyeleri arasında etnik, kültürel, dilsel, dinsel vb. çeşitliliğin bir arada barış ve huzur içinde yaşamasını temin edecek yasallaştırmayı sağlayamamış, bu farklı yapılar arasında bir tür birlik hissinin oluşturulması konusunda başarı kaydedememiştir.

Oysa İslam düşünce tasavvurunda esas alınan sürekli olarak "hakikat" olmuştur. Hakikat, kendisinin dışında var olanları ötekileştirmeden, öteki temelinde fakat bir gerçeklik olarak görmüş onları yok saymamıştır. İslam hukukunun geçerli olduğu toplumlarda İslam dışındaki dinlere hukuki bir statü verilerek temel hak ve özgürlüklerini güvence altına almaya çalışmıştır. Bunun en iyi örneklerini İslam'ın ilk dönemindeki Medine Sözleşmesi, Endülüs ve Osmanlı tecrübesinde net bir şekilde görebiliyoruz (Özensel, 2016, s. 14).

$\mathrm{Bu}$ tecrübenin farklı coğrafyalarda güzel örnekler olarak ortaya çıkmasında, dağınık ve zayıf bir kültür coğrafyasında ortaya çıkan İslam dininin, kendi kültür ve medeniyet kodlarını özgür bir şekilde oluşturma şansına sahip olmasının büyük etkisi vardır.İslamın doğuşundan yaklaşık yüz yıl sonra İslam'ın coğrafi sınırları genişleyip ilk Müslümanlar farklı kültür ve medeniyetlerle karşı karşıya geldiklerinde, kuşatıcı bir dünya görüşüne ve güçlü bir "ben" bilincine sahiptiler. Bu bilinç kendilerine olan güveni arttırırken arkalarında vahye dayalı güçlü bir mesajında farkındaydılar. Çünkü İslam medeniyetinin kurucu unsurları, İslam dininin temel kaynaklarıydı. Vahiy olarak gönderilen Kur'an ve onun hayata geçirilmiş biçimi olan Hz. Peygamber'in Sünneti, sadece ilk Müslümanların değil, İslam medeniyetinin de temellerini oluşturmuştu. Kısa sürede gelişen mimari, sanat, kelam, felsefe, tasavvuf, hukuk, dini ilimler, Müslüman olmayan dini ve kültürel gruplarla olan ilişkiler, siyasi yönetim biçimi ve temel ekonomik kurallar, bu iki temel kaynaktan sürekli olarak beslenmişlerdi (Kalın, 2016, s. 44).

SEFAD, 2020; (43): 369-378 
Tüm bunların yanı sıra İslam, temel ilkelerini ortaya koyarken, kendi dışındaki kültür ve değerleri yok saymamış, herhangi bir toplumda var olan gelenekler konusunda da genel prensiplerini belirlemiştir. Tevhide ve İslam'ın temel ilkelerine aykırı olmayan unsurları olabildiğince hoş görmüştür. İslam hukukunda yer alan "Ehl-i Kitap" ve "Zımmi" kavramları bu anlayışın pratikte yerleşmesine neden olmuştur. Böylece farklılık ve çoğulculuk toplumsal yaşamın bir parçası haline gelmiştir (Özensel, 2016, s. 15). Bu yaklaşımın ardında da "öteki"ni "ötekileştirme"den, varolan gerçekliğin bir parçası olarak görme, onu yok saymama ve onunla bir arada yaşayabilme düşüncesinin bir medeniyet tasavvuru olarak bireysel ve toplumsal muhayyilede yer etmesindendir.

\section{SONUÇ}

Bireyler, toplumun hedeflediği idealler, değerler ve inançları doğrultusunda toplumsal kimliklerini oluştururlar. Kimliklerin oluşumunda farklılıklar ya tolera edilerek kabul edilir ya da ön yargılarla ötekilenip dışlanır. Kimliğin iki önemli bileşeni vardır; "farklılık" ve "benzerlik". Farklılık, bireyi ve grubu diğerlerinden ayırıp farklılaştırırken benzerlik ise, bireyi ve grubu diğerleriyle yakınlaştırıp birbirine benzeştirmesidir.

Diğer yandan bireyin sahip olduğu her türlü farklılıklara olumsuz anlamlar yüklenerek, her türlü farklılığı bir tehdit unsuru olarak algılanması da ötekileştirmedir. Günlük yaşamda bireylerin karşılıklı olarak giriştikleri iletişimin doğasında başkalarıyla etkileşim ve karşılıklı ortaklıklar ve paylaşımlar vardır. Aynı zamanda günlük yaşam, toplumsal eylemin bir anlamda karanlık odasıdır.

"Ben" ve "Öteki" arasındaki ilişkinin, birbirini sürekli kıyaslayan, tanımlayan ve yok sayan boyutuyla ontolojik karakterli olduğu söylenebilir. Ancak 'Öteki' kavramı ile 'ötekileştirme' kavramları arasında şüphe götürmez derin anlamsal farklılıklar vardır.

Her dönemde farklılığı dışlayan, yok sayan ya da kabul etmeyen anlayışların yanı sıra tam tersi farklılığı benimseyen hatta kendinden bir parça olarak gören anlayışlar var ola gelmiştir. Bir arada yaşamanın ön koşulu da, herkesin farklılığına saygı gösteren, farklılığı bir zenginlik olarak gören, farklılıkların temel hak ve özgürlük taleplerini ciddiye alan bir anlayışa sahip olmakla ve bunu uygulamakla mümkün olabilecektir.

Batı'nın yakın dönemde daha çok yapmak istediği, 'ben' ve 'öteki' nin varlık olma iddiasının zayıflatılarak 'ben' ve 'öteki' arasındaki çatışmayı kontrol altına almaya çalışmasıdır. Oysa her toplumun farklı değer manzumeleriyle donanmış bir geçmişi ve muhayyilesi vardır. Görüldüğü gibi Batı merkezli söylemler, toplumun üyeleri arasında etnik, kültürel, dilsel, dinsel vb. çeşitliliğin bir arada barış ve huzur içinde yaşamasını temin edecek yasallaştırmayı sağlayamamış, bu farklı yapılar arasında bir tür birlik hissinin oluşturulması konusunda başarı kaydedememiştir.

\section{SUMMARY}

Daily life constitutes the network of social relations and is also the domain of what is ordinary, monotonous and natural. In other words, daily life is an area where the old and the new, the same and the different and the 'other' and the 'me' meet and also where the 'other' is 'otherized'.

Undoubtedly, the image of the other has continued to exist throughout human history, and the other image has been the most important determinant of the relationship with the other. The phenomenon of identity is built on differences and similarities, and it 
determines the limits of the actions of bearers of identity in daily life. Different factors such as religion, race, language, gender, lifestyle, etc. have a central role in the construction of different identities. Today, there are many different debates and approaches about identity, from discussions on the modernity of individual identity to sexist social discourses and to initiatives in nationalism and ethnic politics.

Identity needs difference to exist, thereby securing its own existence as the other. Thus, the difference that stands out in the formation of individual identity is the main feature of the individual that distinguishes it from other individuals, while social identity is each social group's construction of the differences that distinguish itself from other groups on certain themes. Individuals form their identities in an environment of multiple conflicts and position themselves on different axes in different ways, both as the subject and object of these conflicts.

All in all, the precondition for living together is to have an understanding that respects everyone's identity and takes their fundamental rights and demands for freedom seriously and to implement this understanding. The search for identity stems from the need to connect to the community to which the person belongs, find a place there for himself/herself, and have confidence in himself/herself and their society.

It can be said that the relationship between "I" and "Other" is ontological in character with its dimension that constantly compares, defines and ignores each other. However, there are undoubtedly deep semantic differences between the concept of 'Other' and 'othering'. 'The Other' is not a hostile entity, but rather a 'unique' entity that creates an ontological perception of difference with the response it gives to the action directed towards it. "Otherization", on the other hand, is an attitude that is assumed towards an entity outside of its own field of existence, and even threatening it. The focus of a culture of coexistence is how it sees and makes sense of the "other".

It is emphasized in various studies on othering that the two most important factors causing othering are ethnicity and religion. Although ethnic origin basically expresses a physiological difference, the main elements that ethnic differences focus on are mostly seen as phenomena built as a result of social processes.

Inequalities between different ethnicities in society sometimes lead to tensions, threats, mutual hostilities and conflicts. In fact, such perceptions and behaviors between the parties can lead to the deterioration or even collapse of the social structure.

For the West, which positions itself in the center as modern, progressive and possessing a rational mind, the other is described as a subject that does not have Western values. Thus, they have constantly marginalized societies other than their own. Today, although the West frequently voices various discourses to contain the conflict between 'me' and 'the other', it is seen that it is not successful in creating a sense of unity among the different structures and it is othering those other than itself.

In the Islamic thought, on the other hand, the focus has always been on the "truth". Truth saw what exists outside of it on the basis of the other but as a reality, without alienating it, and did not ignore them. As a matter of fact, in the societies where Islamic law dominated in the past, an attempt was made to secure fundamental rights and freedoms of religions other than Islam by giving them legal status. We can clearly see the best examples of this in the Medina Convention in the early period of Islam, Andalusia and the Ottoman experience.

SEFAD, 2020; (43): 369-378 


\section{KAYNAKÇA}

Berger, P. L. ve Luckmann M. (2008). Gerçekliğin sosyal inşası. (V. S. Öğütle, çev.). İstanbul: Paradigma Yayincilik.

Bourdieu, P. (2015). Ayrım: Beğeni yargısının toplumsal eleştirisi. (D. F. Şannan ve A. G. Berkkurt çev.). Ankara: Heretik Yayınları.

Bourdieu, P. ve Wacquant, L. (2012). Düşünümsel bir antropoloji için cevaplar (6. bs.). (N. Ökten çev.). İstanbul: İletişim Yayınları.

Bourse, M. (2009). Melezliğe öəgü, (I. Ergüden çev.). İstanbul: Ayrıntı Yayınları.

Castells, M. (2010). The Power of identity. (2nd. ed.). United Kingdom: Wiley-Blackwell

Certeau, M. (2009). Gündelik hayatın keş̧i I: Eylem, uygulama ve üretim sanatları. (L. A. Özcan çev.). Ankara: Dost Kitabevi.

Chambers, I.(2005).Göç, kültür, kimlik. (İ.Türkmen ve M. Beşikçi çev.). İstanbul: Ayrıntı Yayınları.

Connolly, W. E. (1991). Identity/difference: democratic negotiations of political paradox. London: University of Minnesota Press.

Eagleton, T. (2011). Kültür Yorumları. (Ö. Çelik çev.). İstanbul: Ayrıntı Yayınları.

Goffman, E. (2012). Günlük yaşamda benliğin sunumu. (B. Cezar, çev.). İstanbul: Metis Yayınları.

Ishii, S., Klopf D. and Cooke P. (2010). Worldview in intercultural communication: A religiocosmological approach. In L. A. Samovar, R. E. Porter and E. R. Mcdaniel (Eds.). Intercultural Communication: A Reader (56-64) (13th ed.)USA: Wadsworth.

Işın, E. (1995). İstanbul'da gündelik hayat, insan, kültür ve mekân ilişkileri. İstanbul: İletişim Yayınları.

Kalın İ. (2016). Ben ve Ötesi, İslam-Batı ilişkileri tarihine Giriş. (4. bs.). İstanbul: İnsan Yayınları.

Karakaş, M. (2013) Türkiye'nin kimlikler siyaseti ve sosyolojisi Akademik İncelemeler Dergisi, 8 (2), 1-44.

Keyman, F. (2000). Küreselleşme, deəlet, kimlik/farklılık: uluslararası ilişkiler kuramın yeniden düşünmek, (S. Coşar çev.). İstanbul: Alfa Yayınları

Korkmaz, R. (2008). Aytmatov anlatılarında ötekileşme sorunu ve dönüş izlekleri. Ankara: Grafiker Yayincilik.

Kurtbaş, İ. (2013). Toplumsal hareketler siyasası, Ankara: Detay Yayınları.

McPherson, J. M., Lynn S. L. and James M. C. (2001). Birds of a feather: homophily in social networks. Annual Review of Sociology. 27, 415-444.

Özalp, A. (2014) Ötekileştirme: sembolik etkileşimci bir bakış. Toplum Bilim Dergisi. Temmuz-Aralık 8 (16), 227-235.

Özensel, E. (2016). Bir değer olarak bir arada yaşamak ve öteki, değerler bilançosu. H. H. Bircan ve B. Dilmaç (Ed.), Değerler Bilançosu-Beyaz Kitap (9-12) içinde, Konya: Çizgi Kitabevi Yayınları

Schnapper, D. (2005). Sosyoloji düşüncesinde öteki ile ilişki. (A. Sönmezay çev.). İstanbul: İstanbul Bilgi Üniversitesi Yayınları.

Therborn, G. (1996). European modernity and beyond: The trajectory of European societies 19452000, Londra: Sage Publications.

Yıldırım, A. (2019). Günlük yaşamda farklllkkları ötekileştirme üzerine sosyolojik bir araştırma. (Doktora Tezi), Selçuk Üniversitesi Sosyal Bilimler Enstitüsü, Konya. 